\title{
Bacterial and Fungal Oral Infections Among Patients Attending Dental Clinics in Sana'a City-Yemen
}

\author{
Hassan A Al-Shamahy ${ }^{*}$, Al Kasem MA Abbas ${ }^{2}$, Ameerah Abdullah Mahdie Mohammed ${ }^{1}$ and Abduljabbar \\ M Alsameai ${ }^{2}$ \\ ${ }^{1}$ Faculty of Medicine and Health Sciences, Sana'a University, Republic of Yemen \\ ${ }^{2}$ Department of Maxillo-Facial, Faculty of Dentistry, Sana'a University, Republic of Yemen
}

*Corresponding author: Hassan A Al-Shamahy, Faculty of Dentistry, Sana'a University, P.O. Box 775 Sana'a, Yemen.

Received Date: August 17, 2018

Published Date: Septembert 10, 2018

\section{Abstract}

The aims of this study were to determine the frequency of clinical diagnosis of oral infections and to identify the bacterial and fungal causative agents and their frequency in patients attended the dental clinics at Al-Gumhouri Teaching Hospital in Sana'a cityYemen.

The study carried out for one year, starting in December 2011 and ending in November 2012. The study included 296 patients of whom 153 were males and 143 were females, their ages ranged from 5 to 65 years old, with a mean age of 36.2 years. Clinical and demographic data were collected in standard questionnaire then oral swabs or pus were collected from patients and cultured, isolated and identified using standard laboratory techniques.

The prevalence of different clinical oral infections were $20.6 \%$ for dental abscesses, $19.3 \%$ for periodontal abscesses, $17.6 \%$ for gingivitis, $16.6 \%$ for periodentitis, $10.1 \%$ for dental caries, $8.4 \%$ for pulpitis and $7.4 \%$ for oral thrush. Out of the total 296 cultured swabs, only 217 swabs yielded positive culture with a percentage of $73.3 \%$. Gram-Positive bacteria constituted $67.4 \%$ of the total isolates, where Staph. aureus was the predominant pathogen (43.1\%), whereas, the Gram-Negative bacteria represented only $26.6 \%$ of the total isolates, in which Bacteroides spp was the predominant Gram-Negative isolate (26.6\%), and finally Candida albicans constituted only $6 \%$ of the total micro-organisms.

It can be concluded from this that the prevalence of dental abscesses in oral infections was more common, Staph. aureus was the most common bacterial isolate and Bacteroides spp was positive in more than quarter of the total isolated microorganisms and Strept. mutans occurred in high frequency in dental caries patients.

Keywords: Bacteria; Fungi; Infections; Oral cavity; Sana'a; Yemen

\section{Introduction}

The oral cavity contains some of the most varied and vast flora in the entire human body and it is the main entrance for 2 systems vital to human function and physiology, the gastrointestinal and respiratory system [1]. The human mouth is home to millions of microorganisms, most of them harmless. Under certain conditions, however, some can cause oral infections such as tooth decay or gum disease [2]. Also, the oral cavity may act as a reservoir for several pathogens related to systemic infections $[3,4]$.

Most oral infections originate from the teeth or the gums: the teeth because they are decayed or partly impacted (trapped) from the gum. Food can get caught from areas where a tooth is partially impacted, i.e. partly erupted and partly under the surface, and this can cause an infection to develop. An abscess arising around a partly erupted wisdom tooth can be very serious-from very rare cases the infection can spread down through the neck and into the chest causing a potentially fatal condition. Gum (periodontal) infections occur both when the gums have receded and deep pockets have developed around the teeth, allowing bacteria to grow, or if an abscess has formed [5]. The frequency of different oral infections are varies in communities worldwide effected by host, behaviors, nutrigonal, social factors $[1,4]$. Infections can be caused by bacteria, viruses or fungi. Bacterial infections can arise if a patient is run down or from a weakened state, either because their immune system is from a compromised state (e.g. due to chronic illness), diabetic, on steroids or on antibiotics for a long time. Fungal infections, such as 
candidiasis (oral thrush) can also arise from long term antibiotic use [2]. In addition to bacterial organisms; oral microorganisms can include fungal, protozoal and viral species.

The bacteria include hundreds of types of organisms of which only " 22 predominant ones have been identified [1,6]. The microenvironment of the oral cavity changes with the age of the patient, the eruption or loss of teeth and the appearance of disease states (e.g., caries, periodontal disease). Systemic changes such as pregnancy or drug intake also alter the number and proportion of flora. These changes are due to alterations in the flow and composition of salivary fluid and in the levels and activity of defense components (e.g., immunoglobulins and cytokines) in the saliva $[1,7]$.

The aims of this study were to determine the frequency of clinical diagnosis of oral infections and to identify the bacterial and fungal causative agents and their frequency in patients attended the dental clinics for different oral infections at Al-Gumhouri Teaching Hospital in Sana'a city-Yemen.

\section{Patients, Materials and Methods}

\section{Patients}

This study included 296 patients with different bacterial and fungal oral infection of whom 153 were males and 143 were females. Their age ranged from 5 to 65 years old, with a mean age of 36.2 years old. All enrolled patients attended the dental clinic for different oral infections at Al-Gumhouri Teaching Hospital in Sana'a city-Yemen during a period of about one year, starting in December 2011 and ending in November 2012.

\section{Study design}

This study was a case-finding study.

\section{Study area}

The area of study was Sana'a city-Yemen.

\section{Cases definition}

All patients enrolled in this study, which had a chief complaint of different oral infections and admitted to the dental clinics of AlGumhouri Teaching Hospital in Sana'a city-Yemen during a period of about one year, starting in December 2011 and ending in November 2012.

\section{Data collection and processing}

A questionnaire for each patient was filled with the patient's personal and clinical data. This included the age, gender, occupation and the relevant clinical information regarding the bacterial and fungal oral infections. At initial enrollment in the hospital, cultures were obtained from oral infection sites in order to isolate the different bacterial and fungal causative agents.

\section{Microbiological methods}

One of the two sterile Dacron swabs collected from the studied patients was used for direct microscopic examination by using Gram's stain for detection of Vincent's organisms (Spirochetes' and Fusobacteria) which were seen as Gram-negative long, spindle shaped and trapping (fusiform) rods with rounded ends on one hand, and the other causative microorganisms which were seen as ordinary Gram-positive cocci and budding yeast cells together with Gram-negative pleomorphic rods on the other hand.

The other collected swab was either inoculated into a transport medium (to be cultured later) or directly cultured onto a suitable selected culture medium. In addition, C. albicans was culture into Sabouraud's dextrose agar plate, then incubated aerobically at 35$37^{\circ} \mathrm{C}$ for $24-48$ hours. After that all isolates were processed for identified and typing using cultural standard techniques with some modification according to Forbes et al, 2007.

\section{Data analysis}

The clinical and personal data in addition to the results of culture of the specimens were entered into a questionnaire and analyzed by the Epi Info, Version 6 . The significance of difference in proportion was analyzed by Pearson Chi-square $\left(\chi^{2}\right)$ which is Greater than 3.84 and probability value (p) is less than 0.05 was considered statistically significant.

\section{Results}

The positive culture rate was $73.3 \%$ and $26.7 \%$ of the specimens were negative (Table 1). A 180 (67.4\%) were Gram-Positive bacteria, 71 (26.6\%) were Gram-Negative bacteria and 16 (6.0\%) were $C$. albicans. The most frequent microorganism isolated was Staph. aureus (115 isolates), followed by Bacteroides spp (71 isolates) and Strept. pyogens (38 isolates) with percentages of $43.1 \%, 26.6 \%$ and $14.2 \%$ respectively. Staph. epidermidis and Strept. mutans showed a low prevalence rate with $6 \%$ and $4.1 \%$ respectively. C. albicans rate was $6 \%$ only (Table 2). When we considered, the clinical diagnosis of oral infections, dental abscess was the most predominant episode (61 cases), followed by periodontal abscess (57 cases), gingivitis (52 cases), and periodentitis (49 cases). However dental caries, pulpitis and oral thrush were slightly occur (30, 25 and 22 cases respectively). In addition, there were no significant variations in these episodes between male and female patients (Table 3).

Table 1: Cultural results of the 296 patients with bacterial and fungal oral infections.

\begin{tabular}{|c|c|c|}
\hline Results & No. & $\%$ \\
\hline Positive cultures & 217 & 73.3 \\
\hline Negative cultures & 79 & 26.7 \\
\hline Total & 296 & 100 \\
\hline
\end{tabular}

Table 2: Distribution of the 217 positive culture isolates according to their group and genus.

\begin{tabular}{|c|c|c|}
\hline Isolates & No. & $\%$ \\
\hline Gram positive bacteria & 180 & 67.4 \\
\hline Staph. aureus & 115 & 43.1 \\
\hline Strept. pyogenes & 38 & 14.2 \\
\hline Staph. epidermidis & 16 & 6 \\
\hline Strept. mutans & 11 & 4.1 \\
\hline Gram negative bacteria & 71 & 26.6 \\
\hline Bacteroides spp & 71 & 26.6 \\
\hline Yeasts & 16 & 6 \\
\hline Candida albicans & 16 & 6 \\
\hline Total & 267 & 100 \\
\hline
\end{tabular}


Table 3 : The number and percentage of clinical diagnosis of different bacterial and fungal oral infections among the total studied patients.

\begin{tabular}{|c|c|c|c|c|c|c|c|c|}
\hline \multirow{2}{*}{$\begin{array}{l}\text { Type of } \\
\text { infections }\end{array}$} & Total $n=296$ & & Male $n=153$ & & $\begin{array}{c}\text { Female } \\
n=143\end{array}$ & & \multirow[t]{2}{*}{$\chi 2$} & \multirow[t]{2}{*}{$\mathbf{p}$} \\
\hline & No. & $\%$ & No. & $\%$ & No. & $\%$ & & \\
\hline $\begin{array}{c}\text { Dental } \\
\text { abscesses }\end{array}$ & 61 & 20.6 & 32 & 20.9 & 29 & 20.3 & 0.02 & 0.89 \\
\hline $\begin{array}{l}\text { Periodental } \\
\text { abscesses }\end{array}$ & 57 & 19.3 & 31 & 20.3 & 26 & 18.2 & 0.21 & 0.61 \\
\hline Gingivitis & 52 & 17.6 & 26 & 16.9 & 26 & 18.2 & 0.07 & 0.78 \\
\hline Periodentitis & 49 & 16.6 & 22 & 14.4 & 27 & 18.8 & 1.14 & 0.28 \\
\hline Dental caries & 30 & 10.1 & 20 & 13.1 & 10 & 7 & 3 & 0.08 \\
\hline Pulpitis & 25 & 8.4 & 15 & 9.8 & 10 & 7 & 0.76 & 0.38 \\
\hline Oral thrush & 22 & 7.4 & 7 & 4.6 & 15 & 10.5 & 1.8 & 0.18 \\
\hline
\end{tabular}

$\chi^{2}$ Chi-square $=\geq 3.84$ (significant)

p Probability value $=<0.05$ (significant)

Table 4 : The number and percentage of clinical diagnosis of different bacterial and fungal oral infections in respect to age of the total studied patients.

\begin{tabular}{|c|c|c|c|c|c|c|c|c|c|c|c|c|c|c|}
\hline \multirow{2}{*}{$\begin{array}{l}\text { Age in } \\
\text { years }\end{array}$} & \multicolumn{2}{|c|}{$\begin{array}{c}\begin{array}{c}\text { Dental abscess } \\
\mathrm{n}=61\end{array} \\
\end{array}$} & \multicolumn{2}{|c|}{$\begin{array}{c}\text { Periodental } \\
\text { abscess } n=57\end{array}$} & \multicolumn{2}{|c|}{ Gingivitis $n=52$} & \multicolumn{2}{|c|}{$\begin{array}{c}\text { Periodentitis } \\
\mathrm{n}=49\end{array}$} & \multicolumn{2}{|c|}{$\begin{array}{c}\text { Dental caries } \\
n=30\end{array}$} & \multicolumn{2}{|c|}{ Pulpitis n=25 } & \multicolumn{2}{|c|}{$\begin{array}{l}\text { Oral thrush } \\
n=22\end{array}$} \\
\hline & No. & $\%$ & No. & $\%$ & No. & $\%$ & No. & $\%$ & No. & $\%$ & No. & $\%$ & No. & $\%$ \\
\hline $\begin{array}{l}<16 \\
\mathrm{n}=36\end{array}$ & 5 & 13.8 & 2 & 5.5 & 6 & 16.6 & 8 & 22.2 & 15 & 41.7 & 0 & 0 & 2 & 5.5 \\
\hline $\begin{array}{l}16-25 \\
n=56\end{array}$ & 9 & 16.1 & 9 & 16.1 & 8 & 14.3 & 13 & 23.2 & 8 & 14.3 & 5 & 8.9 & 0 & 0 \\
\hline $\begin{array}{c}26-35 \\
n=64\end{array}$ & 13 & 20.3 & 11 & 17.2 & 15 & 23.4 & 10 & 15.6 & 5 & 7.8 & 5 & 7.8 & 1 & 1.6 \\
\hline $\begin{array}{c}36-45 \\
n=50\end{array}$ & 11 & 22 & 11 & 22 & 7 & 14 & 6 & 12 & 2 & 8 & 11 & 22 & 5 & 10 \\
\hline $\begin{array}{c}>45 \\
\mathrm{n}=90\end{array}$ & 23 & 25.6 & 24 & 26.7 & 18 & 20 & 12 & 13.3 & 0 & 0 & 4 & 4.4 & 14 & 15.5 \\
\hline $\begin{array}{c}\text { Total } \\
\mathrm{n}=296\end{array}$ & 61 & 20.6 & 57 & 19.3 & 52 & 17.6 & 49 & 16.6 & 30 & 10.1 & 25 & 8.4 & 22 & 7.4 \\
\hline
\end{tabular}

Table 4 shows the number and percentage of oral infection clinical diagnosis in respect with age of patients. Dental abscess occurrence was increasing with increasing age in which the highest rate $(25.6 \%)$ occurred in the oldest age group ( $>45$ years) versa the lowest $(13.8 \%)$ was in children under 16 years old. Also, periodontal abscess occurrence was increasing with increasing age in which the highest rate (26.7\%) occurred in the oldest age group (>45 years) vice versa the lowest (5.5\%) was in children under 16 years old. Gingivitis was more frequently occurred in 26-35 years old patients, and periodentitis was more common in younger adults (16-25 years) with rate equal to $23.2 \%$ and children under 16 years old $(22.2 \%)$, while in older age group not exceed $13 \%$. Dental caries was predominant in children under 16 years old (41.7\%), followed by young adult age group (16-25 years) with rate equal to $14.3 \%$.
Pulpitis was very common in age group36-45 years (22\%). Finally, oral thrush was common in older age groups in which $15.5 \%$ of our patients in age group older than 45 years have oral thrush (Table 4).

Staphylococcus aureus was the most causative agents of dental abscess (60.7\%), periodontal abscess (63.1\%), periodentitis (53\%), and in pulpitis (40\%) (Table 5). Bacteroides species was the most causative agents of gingivitis (46.2\%) and in pulpitis (80\%) while low occurrence of Bacteroides species found in dental abscess (16.4\%), periodontal abscess (12.3\%), and periodentitis (20.4\%). Strept. mutans were isolated from 11 patients of dental carries. C. albicans were isolated from 16 out of 22 oral thrush patients (72.7\%); while $27.3 \%$ were negative culture for C. albicans (Table $5)$.

Table 5 : The number and percentage of causative agents in different clinical diagnosis.

\begin{tabular}{|c|c|c|c|c|c|c|c|c|c|c|c|c|c|c|}
\hline \multirow[t]{2}{*}{ Causative agents } & \multicolumn{2}{|c|}{$\begin{array}{c}\text { Dental abscess } \\
\quad n=61\end{array}$} & \multicolumn{2}{|c|}{$\begin{array}{c}\begin{array}{c}\text { Periodental } \\
\text { abscess } n=57\end{array} \\
\end{array}$} & \multicolumn{2}{|c|}{$\begin{array}{c}\text { Gingivitis } \\
\mathrm{n}=52\end{array}$} & \multicolumn{2}{|c|}{$\begin{array}{c}\begin{array}{c}\text { Periodentitis } \\
n=49\end{array} \\
\end{array}$} & \multicolumn{2}{|c|}{$\begin{array}{c}\text { Dental caries } \\
\mathbf{n}=\mathbf{3 0}\end{array}$} & \multicolumn{2}{|c|}{$\begin{array}{c}\text { Pulpitis } \\
n=25\end{array}$} & \multicolumn{2}{|c|}{$\begin{array}{l}\text { Oral thrush } \\
n=22\end{array}$} \\
\hline & No. & $\%$ & No. & $\%$ & No. & $\%$ & No. & $\%$ & No. & $\%$ & No. & $\%$ & No. & $\%$ \\
\hline Staph. aureus & 37 & 60.7 & 36 & 63.1 & 6 & 11.5 & 26 & 53 & 0 & 0 & 10 & 40 & 0 & 0 \\
\hline Strept.pyogens & 0 & 0 & 7 & 12.3 & 0 & 0 & 36 & 73.5 & 0 & 0 & 0 & 0 & 0 & 0 \\
\hline Staph. epidermidis & 6 & 9.8 & 10 & 17.5 & 0 & 0 & 0 & 0 & 0 & 0 & 0 & 0 & 0 & 0 \\
\hline
\end{tabular}




\begin{tabular}{|c|c|c|c|c|c|c|c|c|c|c|c|c|c|c|}
\hline Strept. mutans & 0 & 0 & 0 & 0 & 0 & 0 & 0 & 0 & 11 & 36.7 & 0 & 0 & 0 & 0 \\
\hline Bacteroides spp & 10 & 16.4 & 7 & 12.3 & 24 & 46.2 & 10 & 20.4 & 0 & 0 & 20 & 80 & 0 & 0 \\
\hline Candida albicans & 0 & 0 & 0 & 0 & 0 & 0 & 0 & 0 & 0 & 0 & 0 & 0 & 16 & 72.7 \\
\hline Mixed growth & 9 & 14.7 & 7 & 12.3 & 8 & 15.4 & 19 & 38.8 & 0 & 0 & 6 & 24 & 0 & 0 \\
\hline No growth & 17 & 27.9 & 9 & 15.8 & 22 & 42.3 & 5 & 10.2 & 0 & 0 & 1 & 1 & 6 & 27.3 \\
\hline Total & 61 & 20.6 & 57 & 19.3 & 52 & 17.6 & 49 & 16.6 & 30 & 10.1 & 25 & 8.4 & 22 & 7.4 \\
\hline
\end{tabular}

\section{Discussion}

Dental caries and periodontal diseases have historically been considered as the most important global oral health burdens. The distribution and severity of oral diseases vary in different parts of the world and within the same country or region [8]. To our knowledge, this is one of the first studies conducted in Yemen to determine the frequency of the most common different bacterial and fungal oral infections and the microbial etiology of these disorders.

In our study dental caries was $10.1 \%$ from the total of patients attending our dental clinic, this rate is lower than that reported elsewhere in which dental caries is the most recognized predominant episode [4]. The low rate of dental caries in Yemen might be explained by that Yemeni patients generally will not search for treatment until dental caries complication occurred as dental abscesses etc. Also, it related to the access to the service in which in many developing countries, access to oral health services is limited and teeth are often left untreated or are extracted because of pain or discomfort $[9,10]$.

In our study the prevalence of dental caries was high in the age group less than 16 years (41.7\%) (Table 4 ), this result was roughly similar to that previously reported in Yemen (49.5\%) [11], USA (44\%) [12] and France (50\%) [13] in children under 16 years old. However, our dental caries rate among children was higher than that documented in the US in recent report (16 to 29\%) [14], 2000) and Japan (20.7\%) [15]. The high rate of dental caries in children in developing countries including Yemen can be as a result of growing consumption of sugars and inadequate exposure to fluorides [8].

In the present study, the total prevalence of periodentitis was $16.6 \%$, lower than the $30 \%$ reported from the USA [16]. In addition, in our study, the highest prevalence of periodontitis was in the age group 16-25 years old (23.2\%), this result was higher than that reported in the USA in which it ranged from $5-15 \%$ in roughly the same age group [16]. The variation of periodontitis in different community could be attributed to genetic predisposition, socialcultural-behavioral differences (e.g. smoking, oral hygiene and access to treatment) and nuterional factors [15-17].

In the present study, the prevalence of gingivitis among patients attending dental clinics was $17.6 \%$; this result was similar to that elsewhere $[18,19]$. In this study, the total prevalence of dental abscess was $20.6 \%$, this result was slightly lower than that reported elsewhere in which the rates are ranged from $30 \%$ to $35 \%[20,21]$. The dental abscess rate increase with age increasing in our study in which the highest rate was occurred in group 36-45 years old (25.6\%), similar observation was noticed in USA [22].
In the present study, the oral thrush rate was 7.4\%; this result was slightly lower than that reported in Tanzania (12\%) and in Taiwan (12.9\%) [23]. The higher rate in Tanzania (12\%) [24] and in Taiwan (12.9\%) comparing with low rate of our study, due to that these studies include HIV patients and due to that oral thrush diagnostic criteria in our study is a positive culture for Candida albicans.

In the present study, Gram-Positive bacteria were isolated more frequently than Gram-Negative bacteria as a cause of oral bacterial infection with a percentage of $67.4 \%$ versus $26.6 \%$ (Table 2). This result agreed with a study in Spain with a percentage of $68 \%$ and 30\% for Gram-Positive bacteria and Gram-Negative bacteria respectively [20]. In addition, Staph. aureus was the predominant bacteria isolated in our study in which it counts $43.1 \%$ of total isolated micro-organisms (Table 2). The high frequency of Staph. aureus in mouth infections can be explained by the fact that Staph. aureus often colonizes the mucous membrane of nose, where it can cause endogenous oral cavity infections [25] and the virulence of Staphylococcus aureus by producing various enzymes such as coagulase which clots plasma and coats the bacterial cell to probably prevent phagocytosis. Hyaluronidase breaks down hyaluronic acid and helps in spreading of Staph. aureus [26].

Regarding the dental abscess in our study, the prevalence of Gram-Positive bacteria was $70.5 \%$, this result was lower than that documented in Brazil that counted for $96.6 \%$ of patients [27]. Moreover, the prevalence of Bacteroides spp isolates was $16.4 \%$; this result was lower than that documented in Brazil with $26.7 \%$ [27].

This study results indicate that the macrobiotic of root canals with periapical abscesses have polymicrobial characteristics and are predominated by Gram-Positive cocci. van Winkelhoff has already described the difficulties in isolating these bacterial species through the use of culture methods [28]. Moreover, Dymock et al. [29] and Baumgartner et al. [30] had reported that the different populations have correspondingly different compositions of microbiota or it may be that these species consist of both culturable and non-culturable biotype. Regarding gingivitis the prevalence of Staph. aureus was $11.5 \%$; this result was consistent to that reported by Kondell et al [31] which was 11\%. Regarding periodontitis, Strept. pyogenes and Staph. aureus isolates represented $73.5 \%$ and $53.1 \%$ respectively, these results were lower than that reported in Brazil (80\%) and (82\%) respectively [32]. These two pathogenic bacteria were predominant at the periodontal sites of periodontitis patients. However, the prevalence of Bacteroides spp isolates was $20.4 \%$, this result was lower than that documented by Moore et al [33] which it was $50 \%$, but higher than that reported by 
Rodenburg et al [34] which it was $8 \%$. These bacterial species are frequently found in periodontal sites of patients with gingivitis and periodotitis [17,35].

Dental caries is widely recognized as an infectious disease induced by diet. The main players in the aetiology of the disease are; a) cariogenic bacteria, b) fermentable carbohydrates, c) a susceptible tooth and host and d) time. However, in young children bacterial flora and host defense systems are in the process of being developed, tooth surfaces are newly erupted and may show hypoplastic defects, and their parents must negotiate the dietary transition through breast/bottle feeding, first solids and childhood tastes. Thus, it is thought that there may be unique risk factors for caries in infants and young children $[8,36]$.

The evidence suggests that children are most likely to develop caries if Strept. mutans is acquired at an early age, although this may be partly compensated by other factors such as good oral hygiene and a non- cariogenic diet. In our study 30 patients were suffering from dental caries, Strept. mutans were isolated from 11 patients $(36.7 \%)$ this result was lower than that documented in Poland with $49.3 \%$ positive culture for Strept. mutans [37]. Regarding the oral thrush, $C$. albicans was the most frequent isolated yeast (72.7\%); this result was higher than that reported in Iran (22.4\%) [37].

The variation in the results may be due to differences in sampling techniques, sample sites and subject selection [38]. The cultures which showed no growth in this study were $26.7 \%$, but other cultivation studies found that around $50 \%$ of the oral microorganisms do not grow on conventional artificial culture media in the laboratory due to that various viruses as well as certain non-cultivated bacteria seem to play an important role in the pathogenesis of human oral infections [39-41].

\section{Conclusion}

Under the limitation of this study it was conclude that, the present study has provided useful information about the prevalence of bacterial and fungal oral infections; including dental abscesses, periodontal abscesses, gingivitis, periodentitis, dental caries, pulpitis and oral thrush among patients attending dental clinics in Sana'a city-Yemen. The prevalence of dental abscesses in oral infections was more common among the total studied patients. $S$. aureus was the most common bacterial isolate among the bacterial oral infections. Bacteroides spp was positive in more than quarter of the total isolated microorganisms and Strept. mutans occurred in high frequency in dental caries patients.

\section{References}

1. Najjar T, Rutner TW, Schwartz RA (2008) Bacterial mouth infections. E Medicine 1: 1-3.

2. CDC (2008) Links Between Oral \& General Health.

3. Souto R, Andrade AF, Uzeda M, Colombo AP (2006) Prevalence of nonoral pathogenic bacteria in subgingival biofilm of subjects with chronic periodentitis. Braz J Microbiol 37: 208-215.

4. Al-Jehani YA (2014) Risk factors of periodontal disease: Review of the literature. Int J Dent 2014: 182513.

5. Aass AM, Preus HR, Zambon JJ, Gjermo P (1994) Microbiologic tests in epidemiologic studies: are they reproducible? Scand J Dent Res 102(6): $355-360$
6. Topazian RG, Goldberg MH, Hupp JR (2002) Oral Maxillofacial Infections ( $4^{\text {th }}$ edn). Philadelphia, USA

7. Nishida N, Tanaka M, Hayashi N, Nagata H, Takeshita T, et al. (2005) Determination of smoking and obesity as periodontitis risks using the classification and regression tree method. J Periodontol 76(6): 923-928.

8. Petersen PE (2004) Challenges to improvement of oral health in the 21st century-the approach of the WHO Global Oral Health Programme. Int Dent J 54(6 Suppl 1): 329-343.

9. Harris R, Nicoll AD, Adair PM, Pine CM (2004) Risk factors for dental caries in young children: a systematic review of the literature. Community Dent Health 21(1 Suppl): 71-85.

10. (2010) Prevalence of periodontal disease in US higher than originally estimated. Health Care 48: 54.

11. Al-Haddad AM, Bin Ghouth AS, Hassan HS (2006) Distribution of dental caries among primary school children in Al-Mukalla Area, Yemen. Journal of Dentistry of Tehran University of Medical Sciences 3(4): 195-198.

12. Reisine S, Tellez M, Willem J, Sohn W, Ismail A (2008) Relationship between disadvantage African American caregiver's and child's caries prevalence. Community Dent Oral Epidemiol 36(3): 191-200.

13. Cahen PM, Tutlot JC, Frank RM, Obry-Musset AM (1989) The orodental status of the French population 6-15 years of age. J Biol Buccale 17(1): 31-38.

14. (2000) Oral health in America: a report of surgeon general. National Institute of Dental and Carnio-facial Research.

15. Cobb CM (2008) Microbes, inflammation, scaling and root planning and the periodontal condition. J Dent Hyg 82 Suppl 3: 4-9.

16. Ababneh KT, Abu Hwaij ZM, Khader YS (2012) Prevalence and risk indicators of gingivitis and periodontitis in a Multi-Centre study in North Jordan: a cross sectional study. BMC Oral Health 12: 1-11.

17. Albandar JM, Kingman A (1999) Gingival recession, gingival bleeding and dental calculus in adults 30 years of age and older in the United States, 1988-1994. J Periodontol 70(1): 30-43.

18. Coventry J, Griffiths G, Scully C, Tonetti M (2000) ABC of oral health: periodontal disease. J British Medical 321(7252): 36-39.

19. Brescó-Salinas M, Costa-Riu N, Berini-Aytés L, Gay-Escoda C (2006) Antibiotic susceptipilty of the bacteria causing odontogenic infections. Med Oral Pathol Oral Cir Bucal 11(1): E70-E75.

20. Ramachandran Nair PN, Pajarola G, Schroeder HE (1996) Type and incidence of human periapical lesions obtained with extracted teeth. Oral Surg Oral Pathol Oral Radio Endod 81(1): 93-102.

21. CDC (2005) Preventing dental caries. US Department of Health and Human Services.

22. Anil S, Challacombe SJ (1997) Oral lesions of HIV and AIDS in Asia: an overview. Oral Dis 3 Suppl 1: S36-S40.

23. Matee MI, Scheutz F, Moshy J (2000) Occurrence of oral lesions in relation to clinical and immunological status among HIV infected adult Tanzanians. Oral Dis 6(2): 106-111.

24. Smith AJ, Robertson D, Tang MK, Jackson MS, MacKenzie D (2003) Staphylococcus aureus in the oral cavity: a three-year retrospective analysis of clinical laboratory data. Br Dent J 195(12): 701-703.

25. Dinges MM, Orwin PM, Schlievert PM (2000) Exotoxins of Staphylococcus aureus. Clin Microbiol Rev 13(1): 16-34.

26. de Sousa EL, Ferraz CC, Gomes BP, Pinheiro ET, Teixeira FB, et al. (2003) Bacteriological study of root canals associated with periapical abscesses. Oral Surg Oral Med Oral Pathol Oral Radiol Endod 96(3): 332-339.

27. Rodenburg JP, van Winkelhoff AJ, Winkel EG, Goené RJ, Abbas F, et al. (1990) Occurrence of Bacteroides gingivalis, Bacteroides intermedius and Actinobacillus actinomycetemcomitans in severe periodontitis in relation to age and treatment history. J Clin Periodontol 17(6): 392-399.

28. Dymock D, Weightman AJ, Scully C, Wade WG (1996) Molecular analysis of microflora associated with dentoalveolar abscesses. J Clin Microbiol 34(3): 537-542. 
29. Baumgartner JC, Siqueira JF Jr, Xia T, Róças IN (2004) Geographical differences in bacteria detected in endodontic infections using polymerase chain reaction. J Endodotics 30(3): 141-144.

30. Kondell PA, Nord CE, Nordenram G (1984) Characterizations of Staphylococcus aureus isolates from oral surgical outpatients compared to isolates from hospitalized and non-hospitalized individuals. Int J Oral Surg 13(5): 416-422.

31. Souto R, Andrade AF, Uzeda M, Colombo AP (2006) Prevalence of nonoral pathogenic bacteria in subgingival biofilm of subjects with chronic periodentitis. Braz J Microbiol 37: 208-215.

32. Moore WE, Moore LH, Ranney RR, Smibert RM, Burmeister JA, et al. (1991) The microflora of periodontal sites showing active destructive progression. J Clin Periodontol 18(10): 729-739.

33. van Winkelhoff AJ, Carlee AW, de Graaff J (1985) Bacteroides endodontalis and other black-pigmented Bacteroides species in odontogenic abscesses. Infect Immun 49(3): 494-497.

34. Moore LV, Moore WE, Cato EP, Smibert RM, Burmeister JA, et al. (1987) Bacteriology of human gingivitis. J Den Res 66(5): 989-995.

35. Seow WK (1998) Biological mechanisms of early childhood caries. Community Dent Oral Epidemiol 26(1 Suppl): 8-27.
36. Rozkiewicz D, Daniluk T, Sciepuk M, Zaremba ML, Cylwik-Rokicka D, et al. (2006) Prevalence rate and antibiotic susceptibility of oral Viridans group streptococci (VGS) in healthy children population. Adv Med Sci 51 Suppl 1: 191-195.

37. Khosravi AR, Yarahmadi S, Baiat M, Shokri H, Pourkabireh M (2008) Factors affecting the prevalence of yeasts in the oral cavity of patients with diabetes mellitus. J de Mycologie Médicale 18(2): 83-88.

38. Wilson MJ, Weightman AJ, Wade WG (1997) Applications of molecular ecology in the characterization of uncultured microorganisms associated with human disease. Reviews in Medical Microbiology 8(2): 91-101.

39. Contreras A, Umeda M, Chen C, Bakker I, Morrison JL, et al. (1999) Relationship between herpes viruses and adult periodontitis and periodontopathic bacteria. J Periodontol 70(5): 478-484.

40. Slots J (1987) Detection of colonies of Bacteroides gingivalis by a rapid fluorescence assay for trypsin-like activity. Oral Microbiol Immunol 2(3): 139-141.

41. Aas JA, Paster BJ, Stokes LN, Olsen I, Dewhirst FE (2005) Defining the normal bacterial flora of the oral cavity. J Clin Microbiol 43(11): 57215732

42. Tanaka K, Miyake Y, Sasaki S (2010) Intake of dairy products and the prevalence of dental caries in young children. J Dent 38(7): 579-583. 